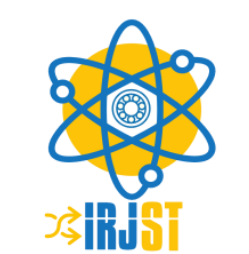

Available online at https://www.irjst.com/

International Research Journal of Science and Technology

ISSN:2707-3955

DOI: https://doi.org/10.46378/irjst.2020.010207

\title{
Allelopathic Potential of Castor plant (Ricinus communis L.) Aqueous Extracts on Germination on Selected Crop Species.
}

\author{
Parreno.J*, Cempron, B, Bucog, N, Pepito, M and Zamora, C \\ Malabog, Paquibato District, Davao City, Philippines.
}

\begin{tabular}{lll}
\multicolumn{2}{l}{ Paper Status } & \\
\hline Received & January 2020 \\
Accepted & $:$ & March 2020 \\
Published & $:$ & March 2020
\end{tabular}

Key Words

Allelopathy

Germination

Ricinus Communis

\begin{abstract}
Weeds in agricultural system are becoming problem nowadays in which it reduces yield of many crops. Synthetic herbicides are usually used to control weed growth. Meanwhile, using herbicides creates hazardous impacts on agricultural products and also increases environmental pollution. Thus, this study aimed to evaluate the allelopahatic potential of Castor plant (fresh leaves, dry leaves, seeds) aqueous extracts on germination rate, germination value indices and root growth on selected crop species. The inhibitory effects of allelochemicals might be used against weeds as a controlling tool for decreasing weed emergence in field conditions. The study consists of 4 treatments replicated 5 times within 7 days. Germination rate, germination value indices and root length were collected in the 7th day of the experiment. Data gathered were analyzed using one way ANOVA and tukey HSD for comparison. Based on the results, it shows that fresh leaves and seed aqueous extract had an allopathic effect on the seed germination and germination value of Zea mays L. and Solanum lycopersicum. In terms of root length inhibition, all treatments had an inhibition effect on the selected crop species. The result showed great potential for the natural herbicide from the determined parts of identified plant.
\end{abstract}

Copyright (C) 2020: Parren. J, Cempron, B, Bucog, N, Pepito, $\mathbf{M}$ and Zamora, C. This is an open access distribution, and reproduction in any medium, provided Access article distributed under the Creative Commons Attribution License the original work is properly cited License, which permits unrestricted use.

Citation: Parreno.J, Cempron, B, Bucog, N, Pepito, M and Zamora, C. "Allelopathic Potential of Castor plant (Ricinus communis L.) Aqueous Extracts on Germination on Selected Crop Species.", International Research Journal of Science and Technology, 1 (2) 120-125, 2020.

\section{Introduction}

Agriculture has been an important part of the growing economy of the Association of Southeast Asian Nations (ASEAN), comprising Brunei, Cambodia, Indonesia, Laos, Malaysia, Myanmar, Philippines, Singapore, Thailand and Vietnam. Member countries are known for its high agricultural productivity and export industry but with varying contribution of agriculture in the gross domestic product (GDP) [1]. However, several problems on production, primarily by weeds, are faced in the region. Weeds have a great impact in agriculture, human activities and the environment.

\footnotetext{
* Corresponding author: Parreno.J

Malabog, Paquibato District, Davao City, Philippines.

Email: ar.jessie27@gmail.com
}

Problems related to yield losses and herbicide resistance were observed [2].

Nowadays, weeds in agricultural systems are extensively present, which reduces yield of many crops. Mechanical methods and synthetic herbicides are usually used to control weed growth. Meanwhile, mechanical methods are labor intensive and time consuming and using herbicides creates hazardous impacts on agricultural products and also increases environmental pollution. Additionally, risk of weed resistance development and high cost-benefit ratio are other disadvantages of synthetic herbicides. Therefore, new approaches such as plant allelopathy have been considered to suppress weed in agricultural system [3].

Aallelopathy is a biochemical interaction considered to be a defensive chemical adaptation in plants and an environmental stress factor for many species. 
Allelochemicals are released into the environment, which inhibit the germination of seeds and/or development of other surrounding plants [4]. Allelopathic plants compete with other plants, by producing different secondary metabolic components such as alkaloids, phenols and glycosides and introducing them to the soil rhizosphere of plants [5]. The species Ricinus communis L. or castor plant is originally native to northeastern Africa and the Middle East. It has escaped cultivation and become naturalized as a weed almost everywhere in the world under tropical or subtropical climate [6]. Thus, this study wants to evaluate the allelopahatic potential of Castor plant (fresh leaves, dry leaves, seeds) aqueous extracts on germination rate, germination value indices and root growth on selected crop species: Vigna radiata L., Solanum lycopersicum L., and Zea mays L. Consequently, the inhibitory effects of allelochemicals might be used against weeds as a controlling tool for decreasing weed emergence in field conditions. The Allelopathic studies represent the alternative and biological search for natural phytotoxins and synthetic derivatives for use as natural herbicides because these compounds show specific action and have a less harmful impact on the environment.

\section{Materials and Methods}

Dry leaves, fresh leaves and seeds of castor plant (R. communis L.) were collected in Brgy. Malabog, Davao City (5'46'38' 'North, 125' 25' 17', East). A certification was issued by Dr. Majella G. Bautista, Ph.D., a member of Association of Systematics Biologist of the Philippines to confirm the plant species used in the study. The aqueous extracts were prepared from dried leaves, seeds and fresh leaves ground in powder form. Ten (10) grams of powdered plant material was added to $100 \mathrm{~mL}$ distilled water and left for 48 hours at room temperature of $(24 o-31$ o C $)$. The extracts were filtered through three layers of filter paper. Aqueous solutions of nine percent were obtained for each plant part of the plant. The methodologies of extraction were adopted [7].

Seeds of Vigna radiata L. (Mung bean), Solanum lycopersicum L. (Tomato), and Zea mays L. (sweet corn) were selected as the test subjects because of the common plant species that were associated with castor plant. Collections of seedlings were bought from locality. Seeds were thoroughly washed by distilled water for 10 to 15 minutes. Five (5) seeds were placed on $90 \mathrm{~mm}$ diameter and $15 \mathrm{~mm}$ height. Each treatment was replicated three times. Treatment $1-$ Control was treated with $2 \mathrm{~mL}$ of distilled water, Treatment $2-$ Fresh leaves extract, Treatment 3 - Seed extract, and Treatment 4 - Dried leaves extracts were treated with the same amount of extract volume in the control.
Every day, seed germination was investigated. Seven (7) days after germination root length was measured. Data are given as rate of germination (\%) and root length (mm).

The data for percentage germination was recorded in the 7th day of evaluation and calculated using the following parameters, germination percentage (GP), mean daily germination (MDG), mean germination time (MGT), coefficient of germination (CG), germination index (GI), peak value (PV) germination value $(\mathrm{GV})$ were calculated using the [8] The traits were calculated as follows: $\mathrm{GP}=(\mathrm{G} / \mathrm{T}) \times 100, \mathrm{MDG}=$ $\mathrm{GP} / \mathrm{Gd}, \mathrm{MGT}=[(\Sigma \mathrm{Gt} \times \mathrm{Dt}) / \mathrm{G}], \mathrm{CG}=100 \times[\mathrm{G} /(\Sigma \mathrm{Gt}$ $\mathrm{x} \mathrm{Dt})], \mathrm{GI}=\Sigma(\mathrm{Gt} / \mathrm{Dt}), \mathrm{PV}=\mathrm{Gpt} / \mathrm{Dpt}, \mathrm{GV}=\mathrm{PV} \mathrm{x}$ MDG. Where $G$ is the total number of germinated seeds, $\mathrm{T}$ is the number of sowed seeds, $\mathrm{Gd}$ is the number of days to complete germination, $\mathrm{Gt}$ is the number of germinated seeds at day $\mathrm{t}, \mathrm{Dt}$ is the days $\mathrm{t}$ from the start of the experiment, Gpt is the cumulative number of seeds already germinated on the day for which the rate of germination first decrease, Dpt is the day previous to the day on which the rate of germination first decreases. Root length was measured in the last day of evaluation. One way ANOVA was used to determine the significant differences in the germination percentage, germination value and root length under different treatments. The levels of significance were set to 0.05 . All data gathered were run and analyzed using $\mathrm{R}$ and $\mathrm{R}$ studio. Descriptive statistics was also used to determine the mean values, 95\% confidence interval and standard error for germination rate, germination speed index and root length in each treatment.

\section{Results and Discussion}

\subsection{Root length}

The effect of R. communis L. aqueous solution on germination percentage (\%) differs from each crop species. Figure 1 shows the germination rate in each crop species. In terms of Zea mays L., it shows that treatment 1 (T1 - water (control)) was not significantly different in Treatment 4 (T4 - Dry leaves). Treatments 2 and 3 (T2 - Fresh leaves and T3 - seed) were significantly lower on germination rate compare to $\mathrm{T} 1$ and T4. For Vigna radiata L., it shows that there was no significant difference in germination rate between treatments. In S. lycopersicum L., it shows that T1 was not significantly different to $\mathrm{T} 3$. Whereas $\mathrm{T} 2$ and $\mathrm{T} 4$ were significantly lower in terms of germination rate compare to $\mathrm{T} 1$ but not significantly lower compared to T3. Based on the observed result, the lowest germination percentage that was recorded among all crop species belongs to $\mathrm{T} 2$ - fresh leaves, were it had a $0 \%$ rate of germination in S. lycopersicum L. and 13\% 
germination rate on $\mathrm{Z}$. mays $\mathrm{L}$. Highest tolerance to allelopathic effect of fresh, dry and seed water extract was observed only at $\mathrm{V}$. radiate $\mathrm{L}$ species, where its germination percentage ranges from $80 \%$ to $100 \%$.

\section{Experimental Procedures, Materials, and Methods}

The result was also observed with other species, where in inhibitory effect of leaf extract of castor bean on seed germination in six cultivated species was known. Aqueous leaf extract of castor plant had the highest inhibition rate among other plant parts [7]. Where jute (Corchorus olitorius), had the highest tolerance of allelopathic chemicals on the study. High inhibitory effects of aqueous extracts of root, stem, leaf and whole plant of R. communis on germination of dodder (Cuscuta compestris) was also observed [5].

\subsection{Germination value indices}

Germination value indices were calculated in the 7th day of experimentation. The following indices were germination percentage (GP), mean daily germination (MDG), mean germination time (MGT), coefficient of germination (CG), germination index (GI), peak value $(\mathrm{PV})$, and germination value $(\mathrm{GV})$. Table 1 shows the calculated germination value indices in each crop species. Base on the results, there was no significant difference between treatments in terms of mean daily germination on $\mathrm{V}$. radiate. In terms of $\mathrm{Z}$. mays, treatment 2 (Fresh leaves) and treatment 3 (seeds) had significantly lower in mean daily germination compared to treatment 1 (control). Treatment 4 (dry leaves) was not significantly different compared to T1. For S. lycopersicum, T1 was not significantly different to T3 but significantly higher in mean daily germination compared to T2 and T4. Where T3 was not significantly different to $\mathrm{T} 2$ and $\mathrm{T} 4$.

Mean germination time (MGT) result had no significant difference on $\mathrm{Z}$. mays. In terms of $\mathrm{V}$. radiate, $\mathrm{T} 2, \mathrm{~T} 3$ and $\mathrm{T} 4$ had no significant differences but significantly higher compared to T1. For S. lycopersicum, $\mathrm{T} 1$ was not significantly different to $\mathrm{T} 3$ but significantly higher in mean daily germination compared to T2 and T4. Where T3 was not significantly different to $\mathrm{T} 2$ and $\mathrm{T} 4$. In terms of coefficient of germination (CG), Z. mays and V. radiata had no significant difference in all treatments. For S. lycopersicum, T1 was not significantly different to T3 but significantly higher in mean daily germination compared to $\mathrm{T} 2$ and $\mathrm{T} 4$. Where $\mathrm{T} 3$ was not significantly different to $\mathrm{T} 2$ and $\mathrm{T} 4$.

In terms of germination index (GI) on Z. mays, T3 and
T2 had the lowest significant germination index compared to other treatments. There was no significant difference in $\mathrm{T} 1$ and $\mathrm{T} 4$. For $\mathrm{V}$. radiata, $\mathrm{T} 1 \mathrm{had}$ significantly higher compared to other treatments. T2, T3 and T4 had no significant differences compared to each other. In S. lycopersicum, T1 was not significantly different to T3 but significantly higher compared to T2 and T4. In terms of peak value (PV), $Z$. mays and V. radiata had no significant difference in all treatments. For S. lycopersicum, T1 was not significantly different to $\mathrm{T} 3$ but significantly higher in peak value compared to T2 and T4. Whereas T3 was not significantly different to $\mathrm{T} 2$ and $\mathrm{T} 4$. For germination value $(\mathrm{GV})$ on $\mathrm{Z}$. mays, $\mathrm{T} 1$ and $\mathrm{T} 4$ were not significantly different from each other but significantly higher compared to $\mathrm{T} 2$ and $\mathrm{T} 3$. Where $\mathrm{T} 2$ and $\mathrm{T} 3$ was not significantly different from each other. In terms of $\mathrm{V}$. radiate, there was no significant difference in all treatments. For S. lycopersicum, T1 was not significantly different to T3 but significantly higher compared to $\mathrm{T} 2$ and $\mathrm{T} 4$.

The presence of phenolic compounds could be the cause of reduced germination rate and growth of selected crop species. R. communis is rich in phenol. Where major phenolic compounds isolated from leaves are the monoterpenoids $(1,8$-cinole, camphor and $\alpha$ pinene) and sesquiterpenoids ( $\beta$ - caryophyllene), gallic acid, quercetin, gentisic acid, rutin, epicatechin and ellagic acid [7]. Allelochemicals like phenol can lead to increased cell membrane permeability resulting in inhibition of plants from absorbing nutrients from the surrounding affecting the growth of plants [10].

\subsection{Root length}

Root length was recorded in the 7th day of data gathering. Root length inhibition was different from each treatment. Table 2 shows the root length of selected crop species after 7 days. Base on the result in terms of Z. mays, Treatment 1 (control) and Treatment 4 (Dry leaves) was not significantly different. While, Treatment 2 (Fresh leaves) and Treatment 3 (Seeds) were significantly lower in root length compared to $\mathrm{T} 1$ and $\mathrm{T} 2$. In terms of $\mathrm{V}$. radiata, $\mathrm{T} 2$ and $\mathrm{T} 3$ were significantly lower in root length compared to $\mathrm{T} 1$ and T4. While, Treatment 4 was significantly lower compared to $\mathrm{T} 1$.

In terms of S. lycopersicum, T2, T3, and T4 were not significantly different from each other but $\mathrm{T} 3$ was not significantly different compared to $\mathrm{T} 1$. Treatment 2 and T4 were significantly lower compared to T1. Standard deviation (SD), standard error (SE) and 
Data are the means $\pm 1 \mathrm{SE}$ of 3 replications. Mean sharing the same letter were not significantly different by Table 1. Germination value indices in each crop species.

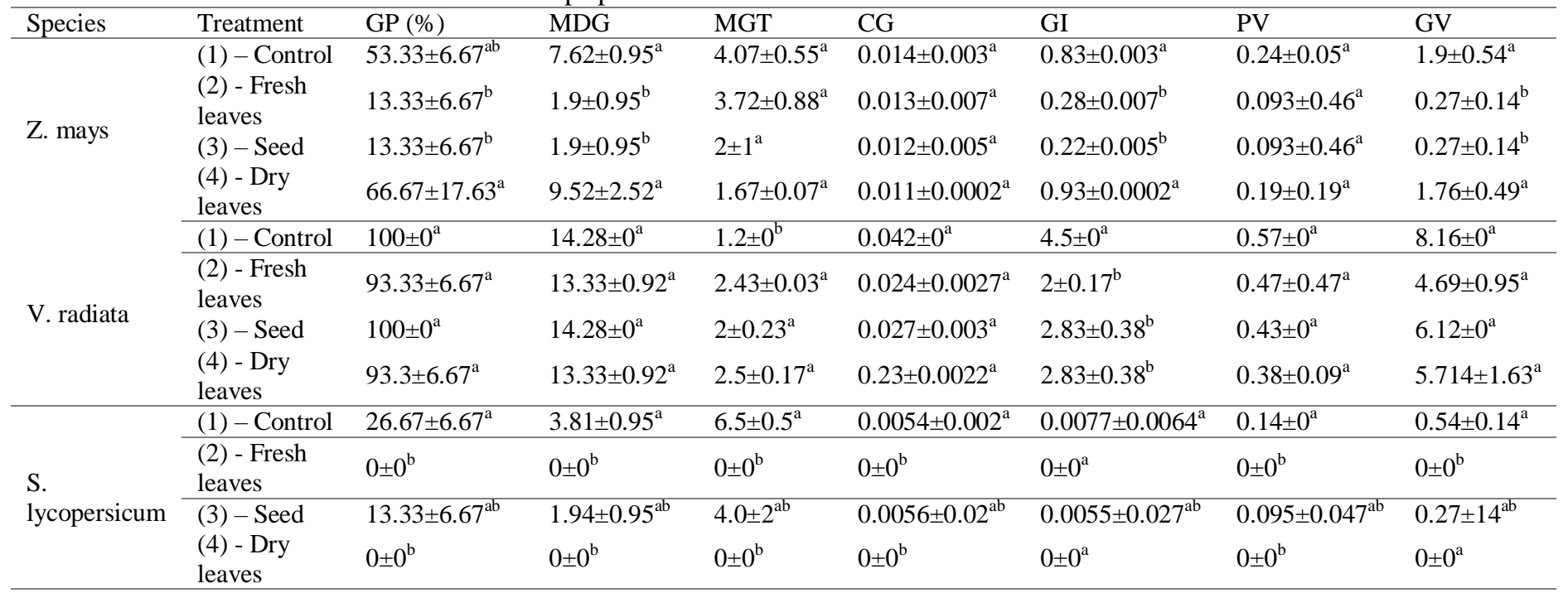

Note : Tukey HSD (P>0.05). (GP) germination percentage, $(M D G)$ mean daily germination, $(M G T)$ mean germination time, $(C G)$ coefficient germination, $(G I)$ germination index, $(P V)$ peak value, and $(G V)$ germination value.

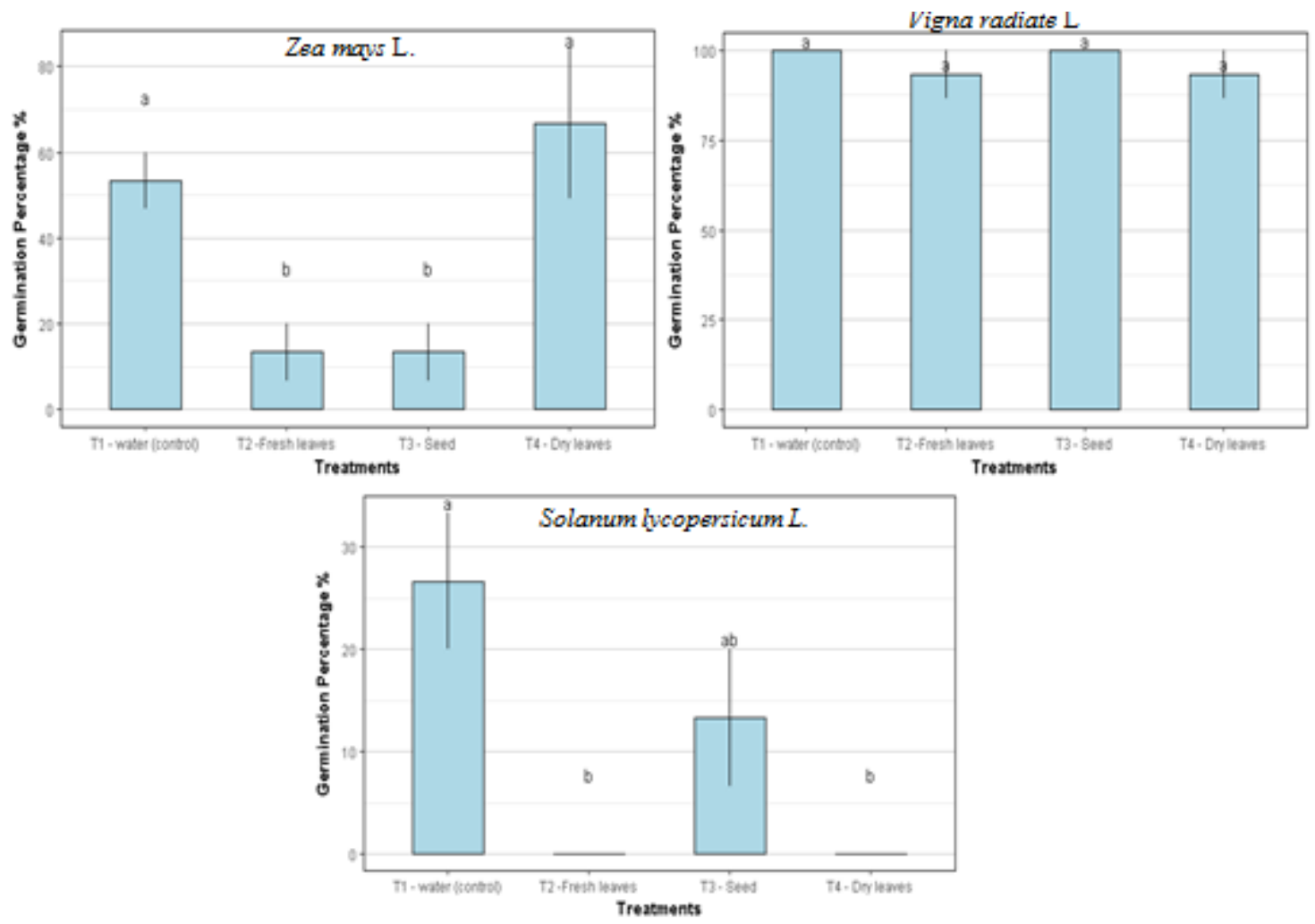

Figure 1. Germination percentage of selected crop species.

${ }^{1}$ Values sharing the same letter is not significantly different 
Table 2. Root length of selected crop species after 7 days

\begin{tabular}{|c|c|c|c|c|}
\hline Treatments & $\begin{array}{l}\text { Root } \\
\text { length }\end{array}$ & SD & SE & CI \\
\hline \multicolumn{5}{|l|}{ Zea mays L. } \\
\hline (1) - Control & $25.4^{\mathrm{a}}$ & 35.26 & 9.1 & \pm 19.52 \\
\hline (2) - Fresh leaves & $1.87^{\mathrm{b}}$ & 5.91 & 1.44 & \pm 3.1 \\
\hline (3) - Seed & $0.53^{\mathrm{b}}$ & 1.6 & 0.41 & \pm 0.88 \\
\hline (4) - Dried leaves & $35.13^{\mathrm{a}}$ & 31.9 & 8.18 & \pm 17.54 \\
\hline \multicolumn{5}{|l|}{ Vigna radiate } \\
\hline (1) - Control & $86.4^{\mathrm{a}}$ & 50.09 & 12.94 & \pm 27.74 \\
\hline (2) - Fresh leaves & $12.8^{\mathrm{c}}$ & 11.13 & 2.87 & \pm 6.16 \\
\hline (3) - Seed & $4.87 \mathrm{c}$ & 2.35 & 0.6 & \pm 1.3 \\
\hline (4) - Dried leaves & $49.67^{b}$ & 28.33 & 7.31 & \pm 15.69 \\
\hline \multicolumn{5}{|c|}{ Solanum lycopersicum } \\
\hline $\begin{array}{l}\text { (1) - Control } \\
\text { (Tomato) }\end{array}$ & $1.8^{\mathrm{a}}$ & 3.59 & 0.92 & \pm 1.99 \\
\hline $\begin{array}{l}\text { (2) - Fresh leaves } \\
\text { (Tomato) }\end{array}$ & $0^{\mathrm{b}}$ & 0 & 0 & \pm 0 \\
\hline (3) - Seed (Tomato) & $0.33^{\mathrm{ab}}$ & 2.35 & 0.23 & \pm 0.49 \\
\hline $\begin{array}{l}\text { (4) - Dried leaves } \\
\text { (Tomato) }\end{array}$ & $0^{\mathrm{b}}$ & 0 & 0 & \pm 0 \\
\hline
\end{tabular}

confidence interval were also showed at the table. Water extracts had inhibitory effect on the root growth of selected crop species. Leaf extract of castor bean inhibited growth of lentil roots [11]. Water extracts of Eucalyptus occidentalis, Acacia ampliceps and Prosopis juliflora inhibit root growth of H. vulgare, M. sativa and C. olitorius [9]. For C. arietinum, inhibitory effect of aqueous leaf extracts of Ficus infectoria, Emblica officinalis and Acacia leucophloea was much pronounced in root development than seed germination [12]

\section{Conclusion}

Base on the results of the study, castor plant $(R$. communis L.) fresh leaves and seed aqueous extracts had an allelopathic effect on the seed germination and germination value of Zea mays L. and Solanum lycopersicum. In terms of root length inhibition, all treatments had an inhibition effect on the selected crop species. With these findings, $R$. communis aqueous extract had a potential herbicide effect on plants.

\section{Acknowledgement}

The researchers would like to express their gratitude to Mr. Bernard Cempron, Mr. Randy B. Alonzo, and Mr. Charles Louie Gonzales for the guidance and assistance that lead to the success and fulfillment of this study.

\section{References}

[1]. Lim, S. S., \& Economics, R. (2015). ASEAN FTA : Is It Creating Agricultural Trades?

[2]. Naz, R., \& Bano, A. (2014). Effects of allelochemical extracts from medicinal plants on physiological and biochemical mechanisms of maize ( Zea mays L .) seedlings. International Journal of Agronomy and Agricultural Research, 5(2), 31-39.

[3]. Nekonam, M. S., Razmjoo, J., Sharifnabi, B., \& Karimmojeni, H. (2013). Assessment of allelopathic plants for their herbicidal potential against field bindweed (Convolvulus arvensis). Australian Journal of Crop Science, 7(11), 1654-1660.

[4]. Dutra Taveira, L. K. P., Silva, M. A. P., \& Loiola, M. I. B. (2013). \&lt;b\&gt;Allelopathy in five species of \&lt;i\&gt;Erythroxylum\&lt;/i\&gt;\&lt;/b\&gt; doi: 10.4025/actasciagron.v35i3.1 6016. Acta Scientiarum. Agronomy, 35(3), 325-331. https://doi.org/10.4025/actasciagron.v3 5i3.16016

[5]. Seyyedi, M., Moghaddam, P. R., Shahriari, R., Azad, M., \& Rezaei, E. E. (2013). Allelopathic potential of sunflower and caster bean on germination properties of dodder ( Cuscuta compestris ). African Journal of Agricultural Research, 8(7), 601-607. https://doi.org/10.5897/AJAR12.2136.

[6]. Kota, O. U. (2014). International Journal of Research in Ricinus Communis ( Castor ): An overview, 3(2), 136-144.

[7]. Saadaoui, E., Martín, J., Ghazel, N., Romdhane, C., Massoudi, N., \& Cervantes, E. (2015). Allelopathic Effects of Aqueous Extracts of Ricinus communis L. on the Germination of Six Cultivated Species. International Journal of Plant \& Soil Science, $7(4)$, 220-227. https://doi.org/10.9734/IJPSS/2015/16483.

[8]. Xu, Y., Cai, N., He, B., Zhang, R., Zhao, W., \& Mao, J. (2016). Germination and early seedling growth of Pinus densata Mast . provenances. Journal of Forestry Research, 27(2), 283-294. https://doi.org/10.1007/s11676-015-0186-X.

[9]. Iqbal, J., Zaib, S., Farooq, U., Khan, A., Bibi, I., \& Suleman, S. (2012). Potential of Aerial Parts of Periploca aphylla and Ricinus communis, 2012. https://doi.org/10.5402/2012/563267

[10]. Li, Z. H., Wang, Q., Ruan, X., Pan, C. De, \& 
Jiang, D. A. (2010). Phenolics and plant allelopathy. Molecules, 15(12), 8933-8952. https://doi.org/10.3390/molecules15128933

[11]. Saadaoui, E., Ghazel, N., \& Ben Romdhane, C. (2014). Allelopathic Effects of Aqueous Extracts of Eucalyptus occidentalis, Acacia ampliceps and Prosopis juliflora on the Germination of Three Cultivated Species. Tunisian Journal of Plant Protection, 11(1).

[12]. Siddiqui, S., Yadav, R., Yadav, K., \& Wani, F. (2009). Potentialities of Different Concentration of Aqueous Leaf Extracts of Some Arable Trees on Germination and Radicle Growth of Cicer arietinum Var.-C235. Global Journal Of, (March 2016). Retrieved from https://www.researchgate.net/ profile/ Sudarshana_Sharma3/ publication/ 237545383_Allelopathic_Potentialities_of_Dif ferent_Concentration_of_Aqueous_Leaf_Extr acts_of_Some_Arable_Trees_on_Germination _and_Radicle_Growth_of_Cicer_arietinum_V ar_-_C-235/links/56e05. 